\title{
Reported Speech as a Supraphrasal Unity
}

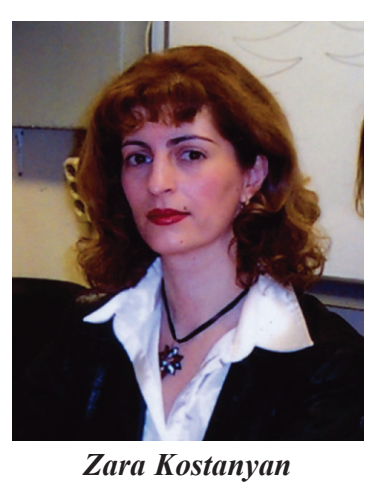
(1965: 115) and Z. Schmidt (1978: 89-110) hold that in conversing speakers do not usually limit their speech to uttering single sentences. This can be true of reported speech as well since it constitutes a transformed version of direct speech.

Reported speech In English has always been an object of numerous studies. However, in almost all studies on the subject the analysis of reported speech, particularly its transposition from direct speech, has mainly been carried out on the basis of an isolated sentence. We find this approach not quite plausible, since our speech cannot be restricted to a single sentence, i.e. direct speech is normally represented by more than one sentence, and consequently, it should also be transmitted into reported speech by a unit larger than a single sentence.

Our goal is to examine reported speech as a supraphrasal unity, which is acknowledged as a unit of the text, larger than a sentence.

As we know, reported speech doesn't reproduce the speaker's (Speaker 1) utterance word for word, but reports it on behalf of another speaker (Speaker 2), which leads to a considerable change of the syntactic and semantic structure of direct speech. Here it is worth citing E. Black, who says, "In general terms, it seems likely that novelists use direct discourse for what they consider to be the more significant utterances, while relegating the less important to indirect discourse, with its potential for summarising and brevity" (Black 2006: 69). Sharing on the whole this view, we cannot but observe that reported speech may sometimes play a very important role in describing the characters of a literary work from different angles. Therefore reported speech requires detailed examination in view of its difference from direct speech.

The important features of the transformation of direct speech into indirect are 1) the arrangement of reported speech as parts of a complex sentence with the mention of Speaker 1 in the main sentence; 2) the use of the subordinating conjunctions that, if, 
whether, etc.; 3) the use of a direct order of words in indirect questions and as a result, the deletion of the auxiliary verb $d o$ in them; 4) the observation of the rules of sequence of tenses on condition that the verb in the main sentence is used in one of the past tenses. 6) the back-shifting of the so-called deictic words (whose meanings are determined by the changes of a speech situation), i.e. the replacement of words of proximal deixis by those of distal deixis).

Our analysis shows that the transformation of direct speech into reported speech on the supraphrasal level brings about more changes than it does in case of an isolated sentence.

In order to see how this transformation works on the supraphrasal level, we will draw a parallel between direct speech and its reported version. It should be noted that usually speech occurs in the text in the form of either direct or reported speech. Naturally, it is rather difficult to come across both forms in the same context. This is particularly evident when we deal with units on the supraphrasal level. But we were fortunate enough to find direct speech and its transformed variant within the same text, which allows us to show some of the changes that attend this kind of transformation.

Below is the example taken from "Seven for a Secret" by V. Holt.

Direct speech:

She (Tamarisk) ... went on: "It might be a little difficult. I can't stay here, can I? I'm here with you as a guest. If you're not here, why should I be? Perhaps Karla would let me have a room here."

(Holt: 326)

Reported speech:

I told her (Karla) that Tamarisk was wondering where she could be when I had gone. She had an idea that she was a guest here because she was accompanying me and naturally, would stay where I was... She thinks that if I'm no longer here she should not be and she should find lodgings.

(Holt: 326)

We will not consider the changes that normally accompany the process of the transformation of direct speech into reported on the sentence level. Rather, we will concentrate on transformations that can be observed on the supraphrasal level. These are as follows. First of all, instead of the five sentences (four simple and one complex) we have three complex sentences in the reported speech. The $1^{\text {st }}$ sentence is a blend of the $1^{\text {st }}$ and $2^{\text {nd }}$ sentences of direct speech; the $2^{\text {nd }}$ sentence is a combination of the $3^{\text {rd }}$ and part of the $4^{\text {th }}$ sentence and finally, the $3^{\text {rd }}$ sentence is a blend of the other part of the $4^{\text {th }}$ and $5^{\text {th }}$ sentences. Each resultant sentence is presented by an introductory clause, which appears here as a result of the transformation of interrogative sentences (sentences 1 and 2) as well as of the modal adverb 'perhaps' (sentence 3): 1. Tamarisk was wondering...; 2. She had an idea ...; 3. She thinks....

These are some of the changes that take place in the process of the transformation of direct speech into its reported variant. Now let's analyse reported speech more 
closely. We will start with the definition of the part of the text containing reported speech consisting of a number of sentences interconnected both semantically and syntactically.

We will call this unit Reported Speech Complex (RSC for short). Each sentence making up a RSC consists of two components: 1) reporting context (RC- the speaker's words) and 2) reported speech (RS - reported speech proper). We will call this unit Reported Speech Structure - RSS). So it will have the following formula: RSS $=\mathbf{R C}$ + RS.

A question arises: How can a RSC be detached from the rest of the text? There are some methods to delimit supraphrasal reported speech: 1) segmenting out the supraphrasal unit on the basis of the structural link between its components; 2) defining the boundaries of the supraphrasal unity from the point of the logical and semantic link between its components. It should be noted that the upper boundary of the RSC is quite definite - it's an RC (the reproducer's words): "He said, "He asked", etc. In order to define the lower boundary of the RSC we take into account the following factors -grammatical, lexical, modal and stylistic. Below are fragments with reported speech, in which the square brackets mark the demarcation line between reported speech and the rest of the text.

1. The grammatical factor: a) the cease of application of the rules of sequence of tenses, b) presence of exclamatory sentences, characteristic of direct speech. Thus for example,

a) He said I was a fool and he preferred Rachel. He said she was a simpleton and knew it. I was one too and didn't. That was the only difference between us. [ Crispin hates him and he hates Crispin]

(Holt)

b) He said he was brought up in France. He said he couldn't speak any English and that's why he couldn't talk to me. [And he couldn't!]

(Fitzgerald)

2. The lexical factor: the use of deictic words oriented at Speaker 2 (i.e. words of proximal deixis). Thus for example,

She told me in that place they pushed them out. They were all too sick. All the hospitals were full, and everybody was dying. [But this place was the worst. If I'm going to die, I'm going to die at home, not in a slaughter.]

(Saroyan)

Could he be saying in public what he was afraid to say in private? That he had wasted his youth on empty promiscuity. But at last was 
changing... growing up? [She now realized why he had left this program till last. For he knew that - perhaps for the first time in his life - he would be speaking from the heart.]

(Salinger)

3. The modal factor: the use of modal words (anyway, perhaps, certainly) pointing to the attitude of Speaker 2 towards the information conveyed by Speaker 1; the evaluation by Speaker 2 of what was said by Speaker 1, etc. For example,

Mal said he didn't mind but he wasn't too crazy about the idea.

[He didn't like Ackley. Anyway, we both went to our rooms to get ready and all.]

(Salinger)

Ted told me on the phone that though it hurt he imagined it was for the best. [He does not know how wrong he is.]

(Segal)

4. The stylistic factor: the use of emphatic and elliptical constructions, including certain stylistic devices. Thus for example,

He would tell her what Colonel Julian said if there was any attempt at blackmail we were to tell him. [They won't dare do it. They can't. It is too dangerous.]

\section{(du Maurier)}

In the last example we observe the use of the contracted forms of the modal and auxiliary verbs, elliptical sentences and also a special stylistic device - gradation indicating the gradual increase of tension of the utterance.

So the consideration of the grammatical, lexical, modal and stylistic factors make it possible to detach supraphrasal reported speech from the larger part of the text.

Now let's concentrate on the means that provide the semantic and grammatical cohesion of the parts of the whole supraphrasal reported speech (RSC). As M.A.K. Halliday asserts cohesion must be considered the most crucial factor in distinguishing text from non-text (Halliday 1976: 195). The semantic cohesion of reported speech is predetermined by its communicative task - a report, a transformation of one form of speech to another.

The means linking the components of supraphrasal reported speech are introduced in two forms: explicit and implicit.

Explicit connection is provided by:

1. subordinating conjunctions - that, if, whether, etc., which may be found on the sentence level as well. Thus for example, 
I told her quite truthfully that I did not think she would do any good coming over. That you did not want to see anyone but Mrs.de Winter.

(du Maurier)

The director of the camp had driven to Baltimore to tell them in person... How Jim's mother had been a Baltimorean herself, born the year Babe Ruth was playing for the Orioles. How Jim's tomato plants had been acting queerly, producing only tiny green marbles that fell off the vines before they ripened.

2) coordinating conjunctions and, so, also, but, still, besides, etc

a) He replied that it was his dream to go to Harvard - like his father. But of course, he had to do his army service first.

(Segal)

b) He says Karen was drunk, talking loud to some reporter starting to make a scene. So he took her to the apartment.

(Mackinlay)

c) Miki... was going to tell each of them that he has a sister and a brother-in-law in Illinois. He also had profession. And besides, Charles Lancaster was willing to be his sponsor.

3) syntactic parallelism

(Segal)

Smith said that Roy was a time server. He said he was a snob. He said he was a humbug.

(Maugham)

She told me to leave her alone. She told me to get out and leave her alone.

(Mc Bain)

Syntactic parallelism may imply repetition of only part of the structure as in

He kept asking if this character was sober. And if I was sober.

(Maugham)

Implicit connection is based on the logical-semantic relations that exist between the constituents of supraphrasal reported speech. These relations may be of the following types: 
1. causative-consequential relations

a) He had said more than once that he would like to be rid of him. He was a menace to everyone. He had even disturbed poor Flora. He created unpleasantness wherever he went.

b) She told him that she had not given much time to considering a man in her life. There had been other things in a sense, compensation.

(Mackinlay)

2. appositive relations

The agent gave them the two camera-cases. He told them that the blue case contained a very powerful smoke-bomb. The red case was the explosive.

(Hailey)

3. temporal relations when the inner logical link between the parts of a RSC is determined by the chronological description of a natural course of events.

a) She told Mrs. McPhail that she had no sleep. When the missionary came upstairs from Miss Thompson he prayed till he was exhausted, but even then he did not sleep for long. After an hour or two he got up and dressed himself, and went for a tramp along the bay.

(Maugham)

b) They told me that an ambulance brought me here. There was an injury to my spine. Then they found bone damage and it kept spreading.

(Maugham)

Now we will try to give a quantitative characteristics of supraphrasal reported speech, in other words we will find out how many sentences (RSS) supraphrasal reported speech (RSC) may be composed of. The analysis shows that their number may be more than two RSSs. Below are examples to illustrate it:

2 RSS Jason told Eva he was going to pick up a game of tennis. She said she would take a walk and meet him later for dinner.

(Segal)

3 RSS Smith said that Roy was a time server. He said he was a snob. He said he was a humbug.

(Maugham) 
He (Mr Cox) announced that the British Empire was dead and London a morgue. He said that Paris was the centre of the intellectual world, if only because it attracted the best American talent. He declared that no Englishman was capable of understanding modern experimental Art. His arrival in Paris (he added) had no political significance, but he hoped that his presence in the Quarter would prove a rallying centre for all that was best in American and Continental Music, Literature and Art.

(Aldington)

5 RSS British major at the club told me the Italians had lost one hundred and fifty thousand men on the Bainsizza plateau and on San Gabriele. He said they had forty thousand on the Carso besides. He said the fighting was over the year down here and that the Italians had bitten off more than they could chew. He said the offensive in Flanders was going to the bad. If they killed men as they did this fall the Allies would be cooked in another year. He said we were all cooked but we were all right as long as we did not know it.

(Hemingway)

As the examples testify the verbs of reporting are not restricted to the verbs say and ask only, but can be verified by such verbs as add, announce, declare, inquire, etc.

The analysis of the factual material provides evidence that in case of implicit connection the number of RS is greater than in case of the explicit connection. In the RSC, which contains copious descriptions of any kind, the number of RS may excel 8 sentences, but for economic considerations we do not adduce this type of RSS in this article.

To conclude, the basic position we have taken in this article is that supraphrasal reported speech, though similar in a number of features to reported speech of a single sentence, has some specific features, which make it possible to separate it from a larger text unit, a statement which comes to once again confirm the postulate put forward by M.A.K..Halliday and R. Hasan: "A text is not something that is like a sentence, only bigger; it is something that differs from a sentence in kind". (Halliday and Hasan 1976)

These features are defined by the grammatical, lexical, modal and stylistic factors that underlie the transposition of direct speech into reported speech on the supraphrasal level.

\section{References:}

1. Black, E. (2006) Pragmatic Stylistics. Edinburgh University Press Ltd.

2. Firth, J.P. (1957) A Synopsis of Linguistic Theory // Studies in Linguistic Analysis. Oxford: Oxford University Press. 
3. Halliday, M.A.K.; Hasan R. (1976) Cohesion in English. Longman.

4. Halliday, M.A.K. (1977) Text as a Semantic Choice in Social Contexts // Research in Text Theory. Grammars and Descriptions. / Ed. by Teun A. van Dijk and Janos S. Petofi. Berlin - New York: Walter de Gruyter.

5. Hartman, P. (1965) Zur Antropologischen Funtierung de Sprache // Symbolae Linguisticae in honore G. Kurylowicz. Warzawa.

6. Kolshanski, G.V. (1980) Kontekstnaya semantika, Moskva: Nauka.

7. Shmidt, Z. (1978) «Tekst» $i$ «istoriya» kak bazoviye kategorii // Novoye v zarubezhnoy lingvistike. Moskva: Progress. Vip. 8.

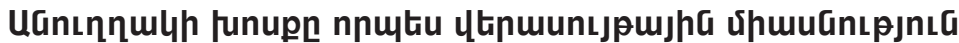

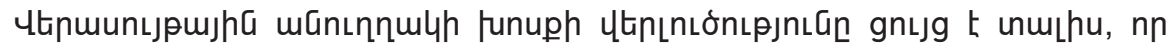

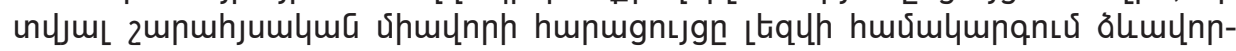

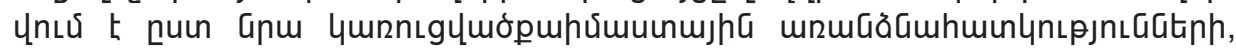

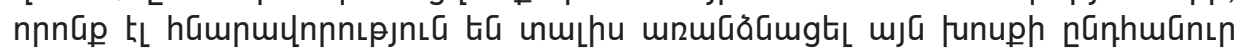

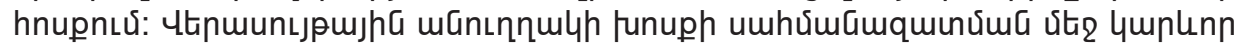

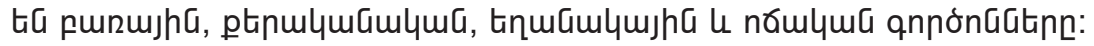

